\title{
Evaluation of Water seepage Along Proposed Baghdad Metro Tunnel Across Tigris River
}

\author{
Aadil A. Hamid ${ }^{1}$, Haitham A. Hussain ${ }^{2 *}$
}

\begin{abstract}
Authors affiliations:
1) Civil Engineering

Department, Al-Nahrain

University, Baghdad - Iraq aadelalbdri@gmail.com
\end{abstract}

$\left.2^{*}\right)$ Civil Engineering Department, Al-Nahrain University, Baghdad - Iraq haitham.alshami@,eng.nahrai nuniv.edu.iq

\section{Paper History:}

Received: $20^{\text {th }}$ Sep. 2021

Revised: $12^{\text {th }}$ Oct.2021

Accepted: $23^{\text {rd }}$ Nov. 2021

\begin{abstract}
Water seepage can cause serious problems in geotechnical engineering especially for construction under the water level. Baghdad metro tunnel is one of the leading vital projects to solve the major problem of crowding roadways in a highly population increase city like Baghdad. In this study, the seepage rate that will flow toward different selected points along the tunnel section across Tigris River was calculated during the excavation process, with the consideration of three different water levels of River at maximum, moderate, and minimum water depths. A three-dimensional model of the study has been modeled using the finite element software (PLAXIS 3D V20). The water seepage was observed for six different locations on each route of the tunnel. The study showed that the change of water depth in the river has no significant effect on the seepage - time curve shape. However, increasing the water level in River from minimum to maximum leads to increase the seepage rate about $15 \%$.
\end{abstract}

Keywords: Baghdad Metro, Seepage Rate, Plaxis 3D, Water Seepage

$$
\begin{aligned}
& \text { تقييم تسرب المياه على طول نفق مترو بغداد المقترح عبر نهر دجلة }
\end{aligned}
$$

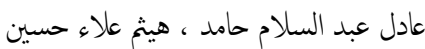

$$
\begin{aligned}
& \text { يمكن أن يسبب تسرب المياه مشاكل خطيرة في الهندسة الجيوتقنية خاصة بالنسبة للمنشآت التي يتم بنائها تحت مستوى }
\end{aligned}
$$

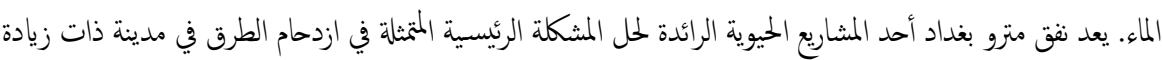

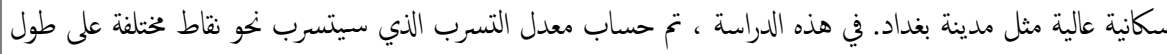

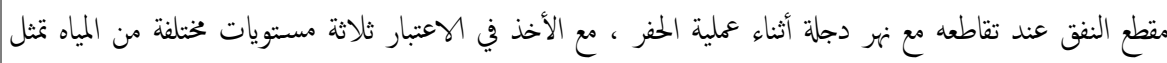

$$
\begin{aligned}
& \text { المعدلات القصوى والمتوسطة والدنيا لمستوى منسوب ماء النهر تم تصميم واعداد نموذج ثلاثي الأبعاد للدراسة باستخدام }
\end{aligned}
$$

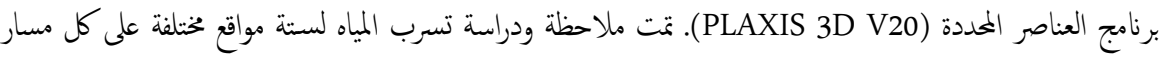

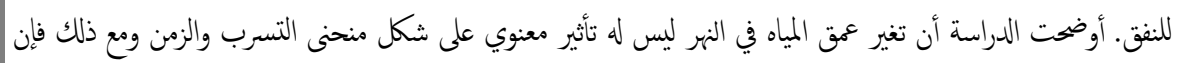

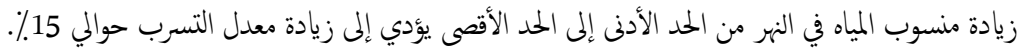

\section{Introduction}

Underground infrastructures have been hugely developed in the past decade due to the increasing demand of residents of urban cities for new mass transportation medias [1]. They are playing a very important role in the lives of now-day people. These substructures include underground parking areas, tunnels, highways, and subways [2]. One of the most important factors to consider when designing a tunnel below the ground water table is the seepage rate, since it may cause tunnel instability, worker life loss, ground settlement, and many other disastrous [3]. Water seepage is unfavorable for tunnel face stability because it is associated with the occurrence of hydraulic gradients in the ground ahead of the excavation face. The hydraulic head gradient acts as a body force, "seepage force", which is directed towards the face and is, therefore, unfavorable with respect to its stability, [4]. Tunnels can be drilled by a tunnel boring machine (TBM) to minimize inflows and groundwater impacts, restricting the effect on the tunnel face. This method is especially suitable for urban tunnels where the works are usually undertaken near the ground surface [5]. Several solutions have been presented in the past decade to evaluate the value of seepage rate and seepage force. (Goodman E.R., et.al. 1965) Considering the case of a tunnel excavated under a large river, Goodman created a simple equation to

NJES is an open access Journal with ISSN 2521-9154 and eISSN 2521-9162

This work is licensed under a Creative Commons Attribution-NonCommercial 4.0 International License 
calculate the seepage force around a tunnel constructed in a homogeneous isotropic semi-infinite aquifer, by application of method of images. Goodman's equations are based on very simple assumptions that the tunnel is of infinite length, and that the water table remains constant without changing its position all the time. Further, he considers the only factor affecting the seepage rate is the permeability coefficient of soil [6,7]. In 1993, Zhang, Franklin showed that the seepage rate obtained by the above equation is insignificant, because actual flow rate obtained from field measurements was $90 \%$ lower and $30 \%$ higher than that given by equations [8]. Heuer in 1995, Found that, the actual water inflow is largely lower than that obtained by Goodman equation; he states that the value is one eight of previous analytical solutions $(87.5 \%$ lower than that given by Goodman equation; he suggested modifying Goodman equation by multiplying by (1/8) [9]. In 1999, El-Tani, took into consideration all the previous known equations, to develop an optimum equation for calculating the seepage rate around a tunnel in a saturated, homogeneous, and isotropic aquifer. El-Tani equation is valid for horizontal circular tunnel. Further modification is required in the case of non-circular shaped tunnels, or non-homogeneous soil [10]. Karlsrud. K combined the work of Goodman and Heuer to develop a new equation considering a very deep tunnel. Karlsrud suggested that his equation has smaller error margins compared with Goodman and Heuer equations, even for shallow depth tunnels that are located under the water table [11]. Moon and Fernandez made a new equation to estimate the flow rate into a circular tunnel in saturated soil. The study considers the reduction of soil mass permeability because of the effect of hydro-mechanical coupling. The results are presented in a couple of equations. The first one is for the case of shallow depth tunnels, and the other is for tunnel at great deeps [12]. Jin-Shin studied the ground reaction curve (i.e.: the relationship between internal pressure and radial displacement of a tunnel) of an underwater tunnel subjected to seepage. This curve is significantly affected by existence of seepage. The study included estimating the quantity of water that inflows to the tunnel and the subsequent seepage force based on the hydraulic gradient distribution around the tunnel. The numerical solution of the ground reaction curve with consideration of seepage was then obtained by using (PENTAGON 2D) software. The numerical results showed that the radial distance of the tunnel wall is highly increased as water seeps into the soil due to the seepage force effect [13]. Lewen Zhang studied water inflow into the Tsingtao subsea tunnel based on the principle of superposition. The permeability coefficients of highly weathered layer and moderately weathered layer were determined according to the permeability coefficient of slightly weathered layer. Then, based on the well flow model of infinite confined aquifers, the double water gushing points calculation model was presented, and then the model was simplified into a single water gushing point calculation model. Then, under the conditions of multi-horizontal strata, the equivalent calculation formulas for water inflow were derived.
The water inflow which is affected by the tunnel depth, radius and seawater depth is analyzed. The suggested formula proves its applicability by compared with the results obtained from a numerical finite element software (FLAC 3D) [14]. This study aims to evaluate the seepage quantity as a time-dependent variable during the excavation stage of the tunnel when it crosses the river. A 3-Dimensional-model will be used to estimate the value of water seepage toward different selected points (mentioned in details later) and for different water levels.

\section{Case study for Baghdad metro tunnel crossing Tigris River}

The proposed Baghdad metro lies in Baghdad City. It has a total length equal to $39 \mathrm{~km}$ including 42 stations. This proposed project comprises two lines that connect both sides of Baghdad City; Karkh and Rasafa. The first proposed line (line-1) runs a length of $18 \mathrm{~km}$ and includes 20 stations. The entire length of line- 1 lies in Rasafa. The second proposed line (line-2) runs a length of $21 \mathrm{~km}$ and includes 22 stations as shown in Figure (1). It starts near Uqba bin Nafie Square to the south of Tigris River and ends at two different locations in Karkh, first end in Mansour town to the west of Tigris River, and the second end in Bayaa town to the southwest of Tigris River. This line can be separated into two major parts, Uqba bin Nafie Square Killani part and Killani-Mansour Square part, and one minor part, Mansour Square-Bayaa route. Killani-Mansour square part, occupies $9 \mathrm{~km}$ approximately. This part starts from the central station in Killani square and ends at a point about $250 \mathrm{~m}$ to the west of Baghdad-Basra railway line running on the west of Mansour town. On its way, it bends to the leftward to cross Tigris River to go to Karkh side [15]. The tunnel is circular in cross-section with an inner diameter of (5.7) meters and an outer diameter of (6.3) $\mathrm{m}$; the tunnel consists of two routes, 45 meters apart $(\mathrm{H}=45)$, and the invert level of the tunnel $(\mathrm{z})$ is at a level of (-32.341), as shown in the Figure 2.

\subsection{Soil Stratification}

The study is performed on the section were the second line of the proposed metro tunnel crossed Tigris River on its way from Rasafa to Karkh. The soil stratification used to build the model is obtained from the national enter of lab and construction research and is shown in Table (1). The first layer of soil is $(6.5 \mathrm{~m})$ depth and consists of dense grey-brown silty to very fine gravelly soil. The second layer is extended $(2.1 \mathrm{~m})$ and it includes stiff to very stiff of brown to orangebrown clay. The third layer extended $(17.2 \mathrm{~m})$ below the stiff clay layer, includes grey-brown vert silty fines. The fourth layer is a thin gravelly to very gravelly grey brown sand with a total thickness of $(1.9 \mathrm{~m})$. The fifth layer is almost the same as the third extended to the bottom of the borehole, with a total reached thickness of $(14.09 \mathrm{~m})$. 


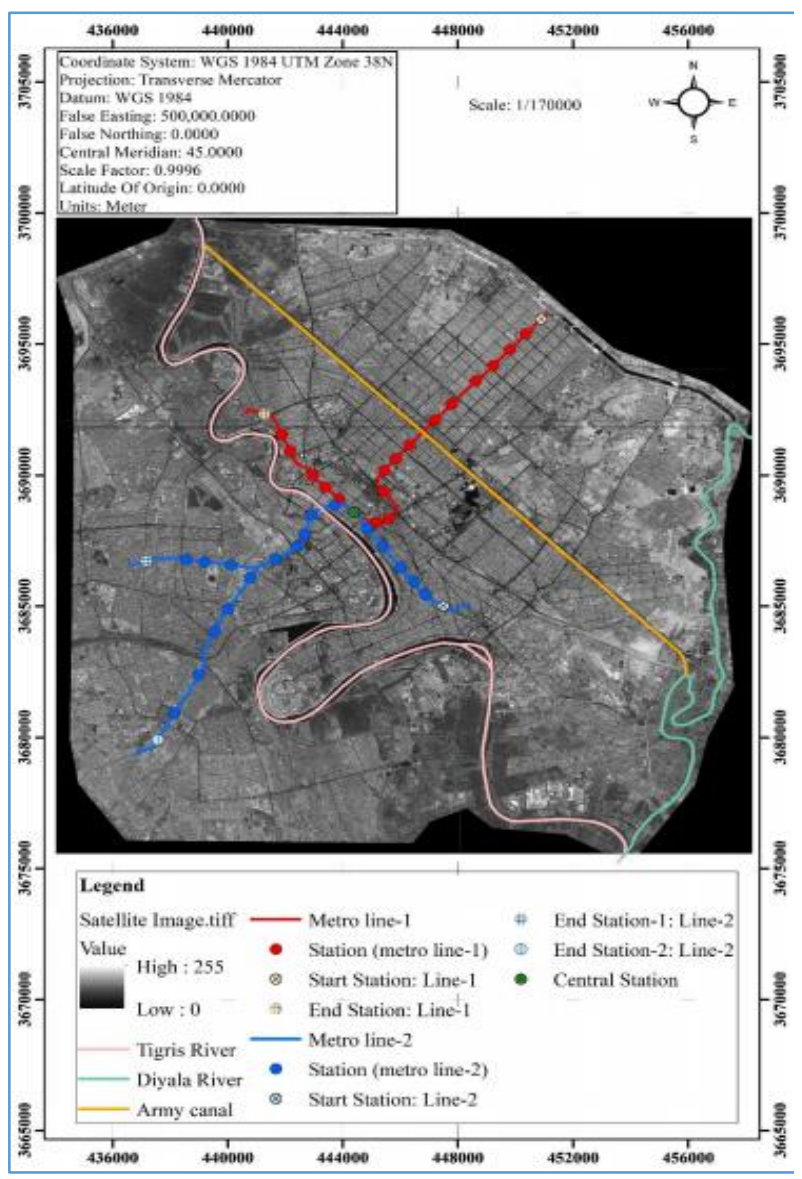

Figure 1: Layout of Baghdad metro plotting on satellite image of Baghdad City (60 cm error). [15]

\section{Methodology}

Numerical software is used to determine seepage rate towards tunnels. The finite element method has been used in geotechnical problems since the 1960s, and thereafter developed in applications of continuum mechanics and structural engineering. This method has the noticeable advantage of applying soils that have a non-linear stress behavior. In this research, the finite element method was selected to conduct the study by the finite element software called PLAXIS 3D CE V20. Developing PLAXIS started in 1987 at Delft University. PLAXIS has been extended to be used in most geotechnical engineering applications. During this time, the kernel calculation of (3D) finite element was developed to release the (PLAXIS 3D tunnel program) in 2001. With a corporate merger with TNO in 2004, the second version of (3D PLAXIS) software called (3D Foundation) was released. The new version of (3D PLAXIS) was released in 2010. The development of three-dimensional (PLAXIS) software which includes an easy way to use it with the facilities of full (3D) modeling. [17].

\section{Numerical Model}

In this section, a three-dimensional model was established to validate the software with other applicable analytical and numerical solutions. The second part of this section illustrates the construction of the computational model for the case study of Baghdad metro.

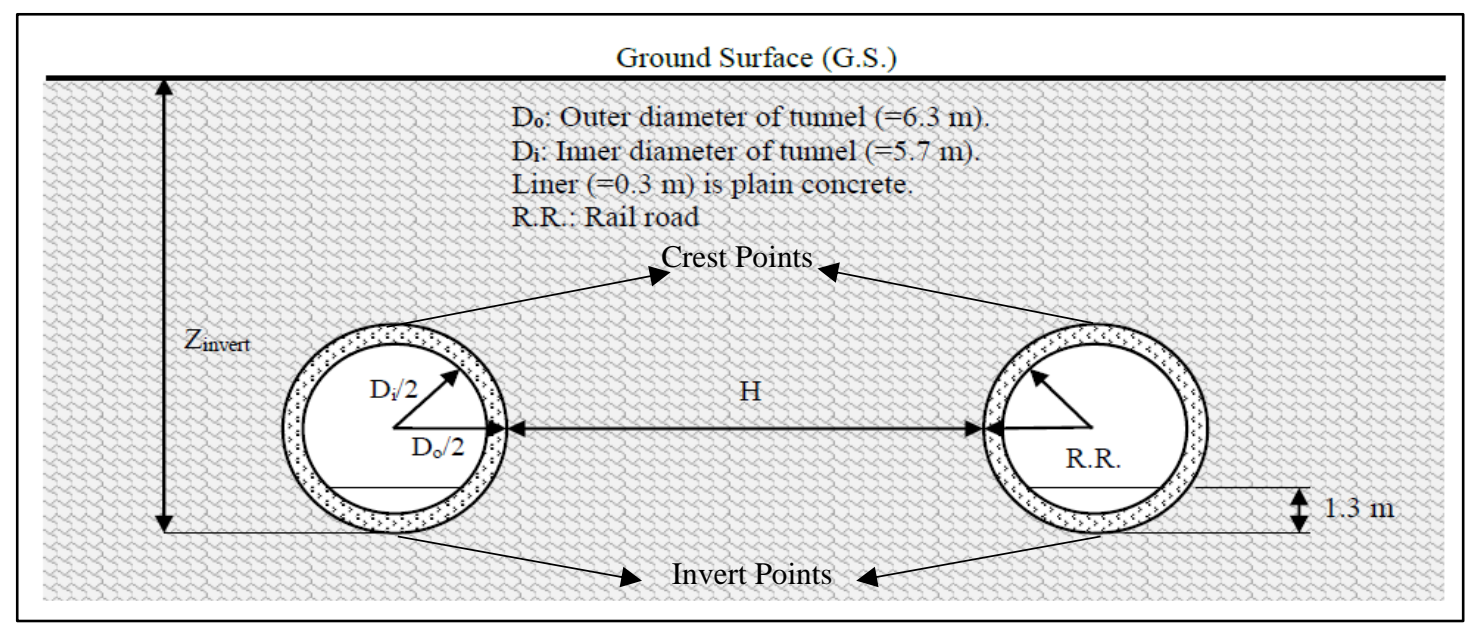

Figure (2): Tunnel section [16].

Table (1): Soil strata properties for location under Tigris [15]

\begin{tabular}{|c|c|c|c|c|c|c|c|c|c|c|}
\hline \multirow{2}{*}{$\begin{array}{c}\text { Layer } \\
\text { No. }\end{array}$} & \multicolumn{2}{|c|}{ Depth of layer (m) } & \multirow{2}{*}{ 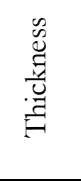 } & \multirow{2}{*}{ 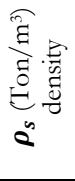 } & \multirow{2}{*}{ 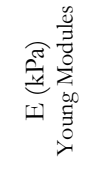 } & \multirow{2}{*}{ 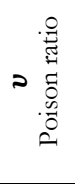 } & \multirow{2}{*}{ 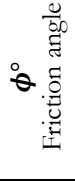 } & \multirow{2}{*}{ 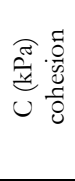 } & \multirow{2}{*}{ 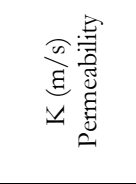 } & \multirow{2}{*}{ ○. } \\
\hline & From & To & & & & & & & & \\
\hline 1 & 0 & 6.5 & 6.5 & 2.23 & 7000 & 0.4 & 25 & 10 & $1.0 \mathrm{E}-8$ & 0.7 \\
\hline 2 & 6.5 & 8.6 & 2.1 & 2.07 & 2528.2 & 0.5 & 5 & 100 & $3.0 \mathrm{E}-7$ & 0.25 \\
\hline 3 & 8.6 & 25.8 & 17.2 & 1.996 & 10000 & 0.45 & 30 & 15 & $5.0 \mathrm{E}-8$ & 0.65 \\
\hline 4 & 25.8 & 27.7 & 1.9 & 2.434 & 17000 & 0.48 & 35 & 14 & $1.75 \mathrm{E}-7$ & 0.75 \\
\hline 5 & 27.7 & 41.79 & 14.09 & 1.996 & 10000 & 0.45 & 30 & 15 & $5.0 \mathrm{E}-8$ & 0.65 \\
\hline
\end{tabular}




\subsection{Verification Model}

Su, K., et.al [18], studied the water inflow toward sub-water circular tunnels excavated in a rock soil. They developed a new analytical equation to determine the quantity of seepage through the rock mass. The case study was conceptualized as two-dimensional streamflow in a plane perpendicular to the tunnel axis. The analytical formula, considering the effect of the excavation-induced drawdown, provides a better prediction of the tunnel inflow compared to the existing analytical formulas, even for cases with inclined groundwater level. The obtained expression was tested and compared its results with those obtained from finite element numerical analysis using ABAQUS software. Figure (3) show a schematic representation of a circular tunnel excavated in a semiinfinite aquifer with infinite width and depth under a horizontal water table. The tunnel case is modeled as a flow problem in two-dimensional plane that is orthogonal with the tunnel axis. Three assumptions were made: (1) The surrounding rock has the homogeneous and isotropic permeability; (2) the fluid is incompressible; and (3) there is no flow along the tunnel axis. A two-dimensional numerical mesh was created with a $10 \mathrm{~m}$ diameter tunnel drilled at 70 to 350 $\mathrm{m}$ beneath the ground surface from the tunnel center as shown in Figure (4). The numerical model boundaries were assumed to be located at a distance not less than 50 times the diameter (D) from the tunnel center to the vertical and bottom boundaries, so that the influence of the boundaries on the tunnel water inflow and pore pressure distribution can be omitted according to Zhou [19]. the permeability of ground surface and the rock layer was $1.0 \times 10-7 \mathrm{~m} / \mathrm{s}$. Very fine mesh was generated; the model consists of (12207) elements and (25096) nodes as shown in Figure (5).

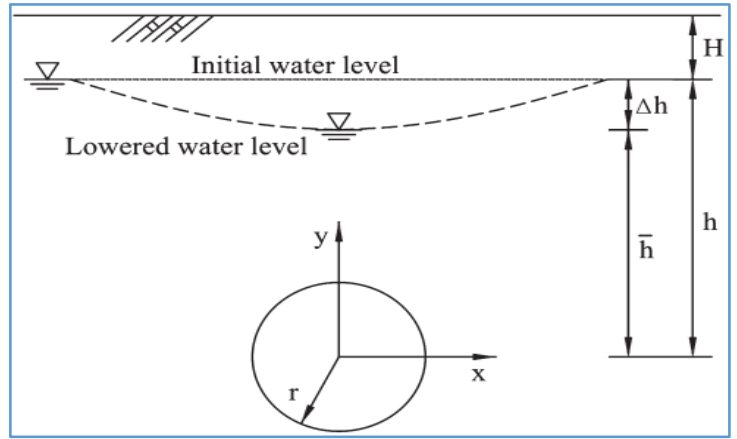

Figure (3): Circular tunnel profile [18].
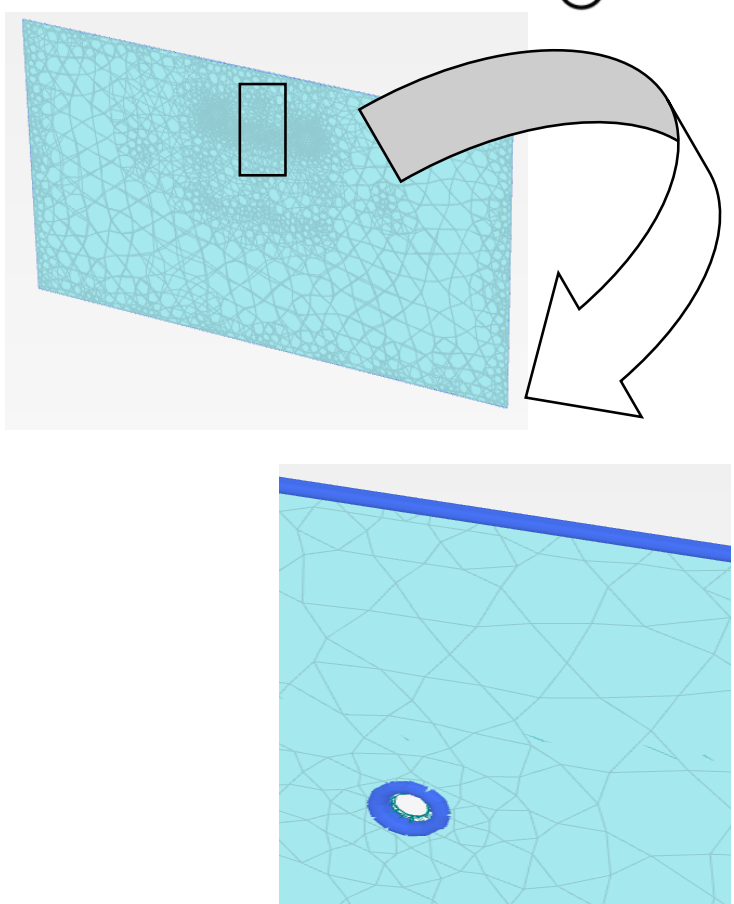

Figure (4): Numerical model (tunnel diameter D = $10 \mathrm{~m}$, the depth from ground surface to the initial water table $\mathrm{H}=50 \mathrm{~m}$, the initial piezometric head above the tunnel center $\mathrm{h}$ is ranged from 20 to 300 m) [18].

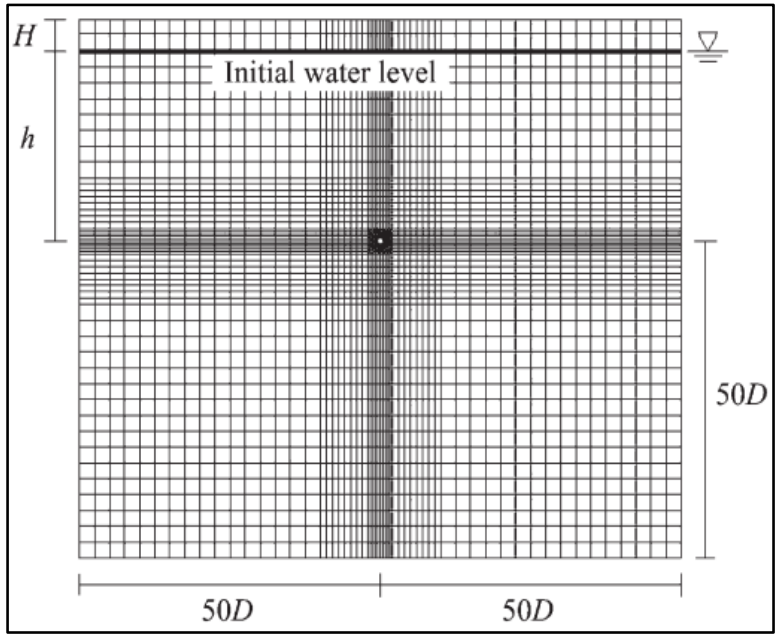

Figure (5): Mesh generation of the validation model by using PLAXIS 3D.

\subsection{Computational model}

In this study, a three-dimensional finite element model using PLAXIS 3d V20 software was constructed to study the effect of water head change on the quantity of seepage rate at different selected points along the tunnel when it passes under the river. The soil stratum has been modeled as a Moher Columb type, and the water table location was selected to be the elevation of the river. Three water table levels have been selected $(6.1,3.9$, and 1.8) meters representing maximum, minimum, and mean depth of the river. [20]. The tunnel has been modeled by using the tunnel design tool, and a fully coupled flow deformation analysis is performed. The finite element mesh extends to a horizontal distance (X-direction) of 8 times the outer diameter from the centerline of each 
tunnel route, to a vertical depth (Z-direction) of 1.5 times the outer tunnel diameter below the tunnel invert for the two tunnel routes. And a distance (in $\mathrm{Y}$ direction) of 8 times of the outer tunnel diameter perpendicular to the vertical depth. The locations of these boundaries have been selected in such a way that the presence of boundaries beyond them has no significant effect on the stress-strain - pore pressure field in the domain [21].

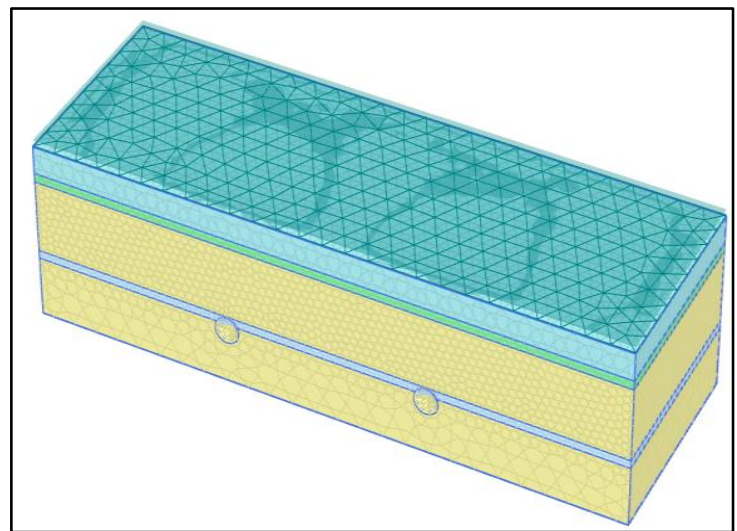

Figure (6): Mesh generation of the finite elements model by using PLAXIS

Six points have been selected on each route to evaluate the variation of the water seepage toward the tunnel (Q) during the excavation phase of tunnel construction. The coordinates of these points are stated in Table (2) below. The excavation phase duration is taken as (10 days), based on the newest study by the design and study company (French firm Sastra) that suggested that the length of tunnel with two sections excavated during one day approximately equals to $5 \mathrm{~m}$ to $5.5 \mathrm{~m}$ [16].

Table (2): Coordinates of selected location for observing seepage rate

\begin{tabular}{|c|c|c|c|c|}
\hline Location & $\mathbf{X}(\mathrm{m})$ & $\mathbf{Y}(\mathrm{m})$ & $\mathbf{Z} \mathbf{( m )}$ & Code \\
\hline $\begin{array}{c}\text { Left route - frontal } \\
\text { crest point }\end{array}$ & -26.56 & 0 & -26.04 & $\begin{array}{c}\text { LR frontal } \\
\text { CR. }\end{array}$ \\
\hline $\begin{array}{c}\text { Left route - frontal } \\
\text { invert point }\end{array}$ & -26.56 & 0 & -32.41 & $\begin{array}{c}\text { LR frontal } \\
\text { Inv. }\end{array}$ \\
\hline $\begin{array}{c}\text { Left route - mid } \\
\text { crest point }\end{array}$ & -26.56 & 25.2 & -26.04 & $\begin{array}{c}\text { LR mid } \\
\text { CR. }\end{array}$ \\
\hline $\begin{array}{c}\text { Left route - mid } \\
\text { invert point }\end{array}$ & -26.56 & 25.2 & -32.41 & $\begin{array}{c}\text { LR mid } \\
\text { Inv. }\end{array}$ \\
\hline $\begin{array}{c}\text { Left route - rear } \\
\text { crest point }\end{array}$ & -26.56 & 50.4 & -26.04 & $\begin{array}{c}\text { LR Rear } \\
\text { CR. }\end{array}$ \\
\hline $\begin{array}{c}\text { Left route - rear } \\
\text { invert point }\end{array}$ & -26.56 & 50.4 & -32.41 & $\begin{array}{c}\text { LR Rear } \\
\text { Inv. }\end{array}$ \\
\hline $\begin{array}{c}\text { Right route - frontal } \\
\text { crest point }\end{array}$ & 26.56 & 0 & -26.04 & $\begin{array}{c}\text { RR frontal } \\
\text { CR. }\end{array}$ \\
\hline $\begin{array}{c}\text { Right route - frontal } \\
\text { invert point }\end{array}$ & 26.56 & 0 & -32.41 & $\begin{array}{c}\text { RR frontal } \\
\text { Inv. }\end{array}$ \\
\hline $\begin{array}{c}\text { Right route - mid } \\
\text { crest point }\end{array}$ & 26.56 & 25.2 & -26.04 & $\begin{array}{c}\text { RR mid } \\
\text { CR. }\end{array}$ \\
\hline $\begin{array}{c}\text { Right route - mid } \\
\text { invert point }\end{array}$ & 26.56 & 25.2 & -32.41 & $\begin{array}{c}\text { RR mid } \\
\text { Inv. }\end{array}$ \\
\hline $\begin{array}{c}\text { Right route - rear } \\
\text { crest point }\end{array}$ & 26.56 & 50.4 & -26.04 & $\begin{array}{c}\text { RR Rear } \\
\text { CR. }\end{array}$ \\
\hline $\begin{array}{c}\text { Right route - rear } \\
\text { invert point }\end{array}$ & 26.56 & 50.4 & -32.41 & $\begin{array}{c}\text { RR Rear } \\
\text { Inv. }\end{array}$ \\
\hline
\end{tabular}

\section{Results and discussion}

This section shows the results of numerical analysis for both the validation and computational models followed by a brief discussion for these results.

\subsection{Results of validation test}

The results of the numerical analysis of water inflow due to the excavation of the tunnel and the change in water depth above the tunnel are shown in Figure (7). By comparing the numerical analysis results with the upper bound solution given by Goodman and the lower bound solution given by Moon, Plaxis results are well-located between them, and are roughly the same as those obtained by Su using ABAQUS.

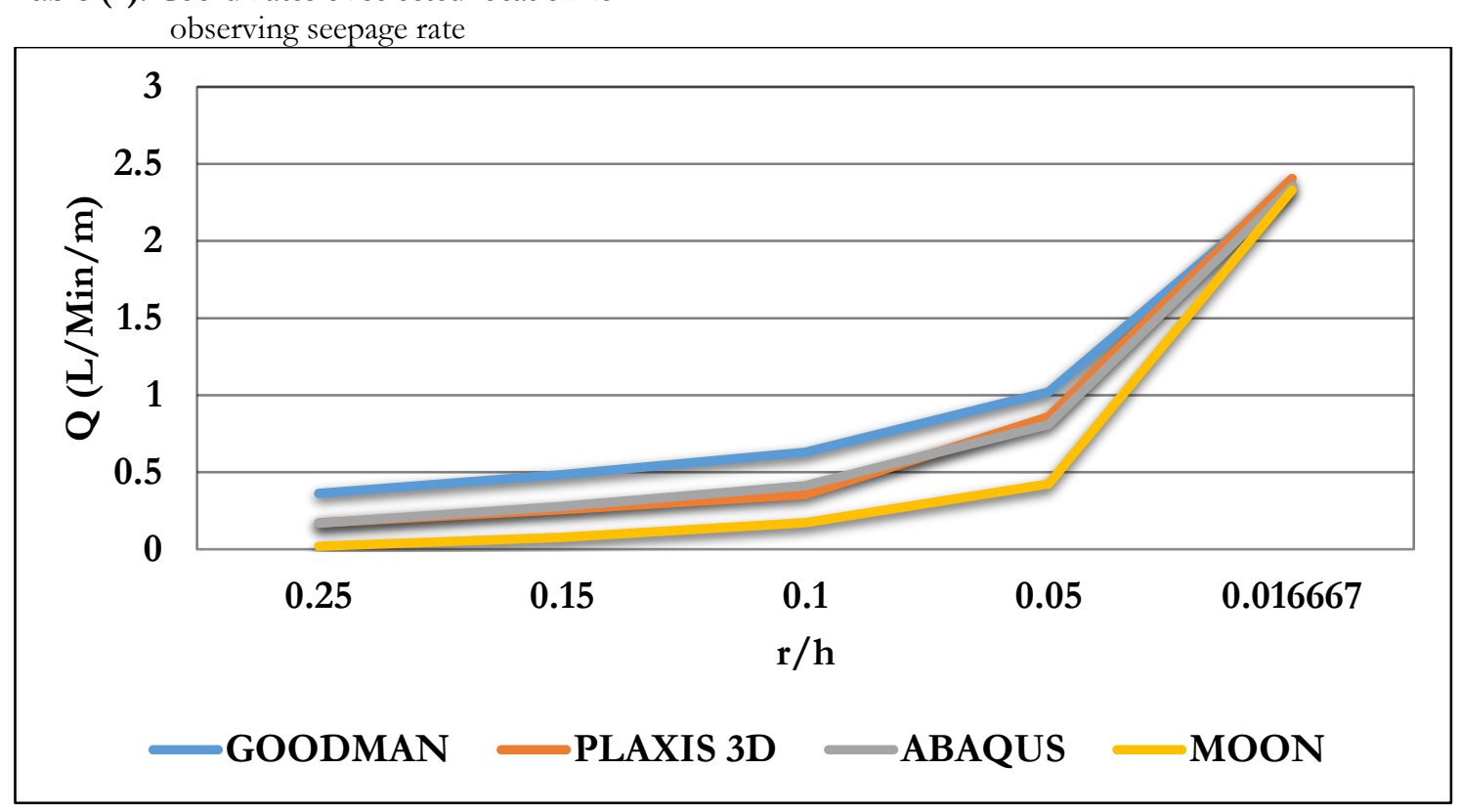

Figure (7): Comparison of PLAXIS results with that of other related software.

\subsection{Results of analytical model}

The seepage rate has been calculated as a time dependent value, and the study results is presented in
Figures $(8,9,10)$. Maximum water seepage occurs on the rear face crest point of the left route with a value of $\left(1.68 \times 10^{3} \mathrm{~m}^{3} / \mathrm{min}\right)$ when the water level is $(6.1$ 
$\mathrm{m}$ ) in the last day of excavation process. For the midsection, the minimum variation between the crest and invert points seepage rate can be noticed for both routes, which lead to more stability as the seepage force related to this water seepage will be approximately equal on top and bottom points. When the water level is minimum (i.e.: $1.8 \mathrm{~m}$ ) the total flow on the frontal crown point of the left route is raised up from (0) in the geostatic step (the step before the beginning of excavation) to a value of $\left(8.1 \times 10^{-4}\right.$ $\mathrm{m}^{3} / \mathrm{min}$ ), few hours after the excavation process start, then this value is kept uniform at the same rate until the end of the excavation process. The frontal invert point seepage - time curve showed the same behavior for the crest point curve, but, for sure with a lower value of water seepage $\left(1.8 \times 10^{-4} \mathrm{~m}^{3} / \mathrm{min}\right)$. The same behavior of frontal face can be seen for the right and left route, with a maximum value of $\left(1.02 \times 10^{-3}\right.$ $\mathrm{m}^{3} / \mathrm{min}$ ) for the crest point. By comparing the results of mid plane crest and invert point of both routes for the minimum water level, it can be clearly seen that the values of water seepage through these points are approximately nil. A maximum value for both left and right crest points of about $\left(4.5 \times 10^{-5} \mathrm{~m}^{3} /\right.$ day $)$ was found to occurring four days after the start of the excavation process then it is gradually decrease to a stable value of $\left(1.25 \times 10^{-5} \mathrm{~m}^{3} /\right.$ day $)$ within two days. While the mid-way invert points of both routes exhibit the maximum value of seepage in three days after the start of excavation process. The maximum value of seepage rate at the mid invert point was found to be approximately $50 \%$ of the water seepage towards the same section crest point, then they go down to almost zero only one day after their peak point. The rear plane points are the most critical points, showed a relatively large gap between the seepage rate at crest and invert points. The seepage rate remains at zero level for the first nine days of ten days excavation process. Then it is gradually raising to the value of $\left(1.5 \times 10^{-3} \mathrm{~m}^{3} / \mathrm{min}\right)$ at the crest point of both routes, and to the value of $\left(1.5 \times 10^{-4} \mathrm{~m}^{3} / \mathrm{min}\right)$ for the invert point of both routes. These values of water seepage on the rear face stay almost constant during the last day as shown in Figures $(8,9,10)$. The same curves behavior can be noticed for the other water level with a little larger value. The maximum value water seepage for the rear crest point of the left and right routes for water level of $(6.1 \mathrm{~m})$ was found to be $\left(1.68 \times 10^{-3}\right.$ $\left.\mathrm{m}^{3} / \mathrm{min}\right)$ and $\left(1.6 \times 10^{-3} \mathrm{~m}^{3} / \mathrm{min}\right)$ respectively.
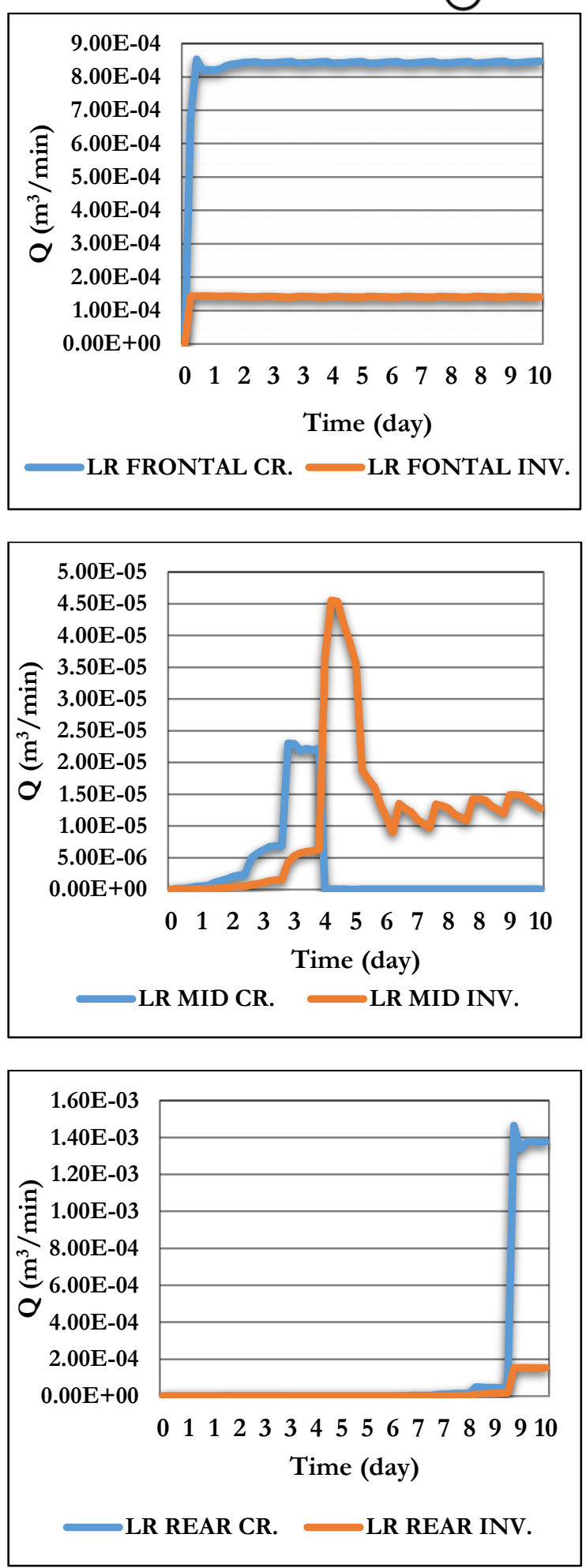

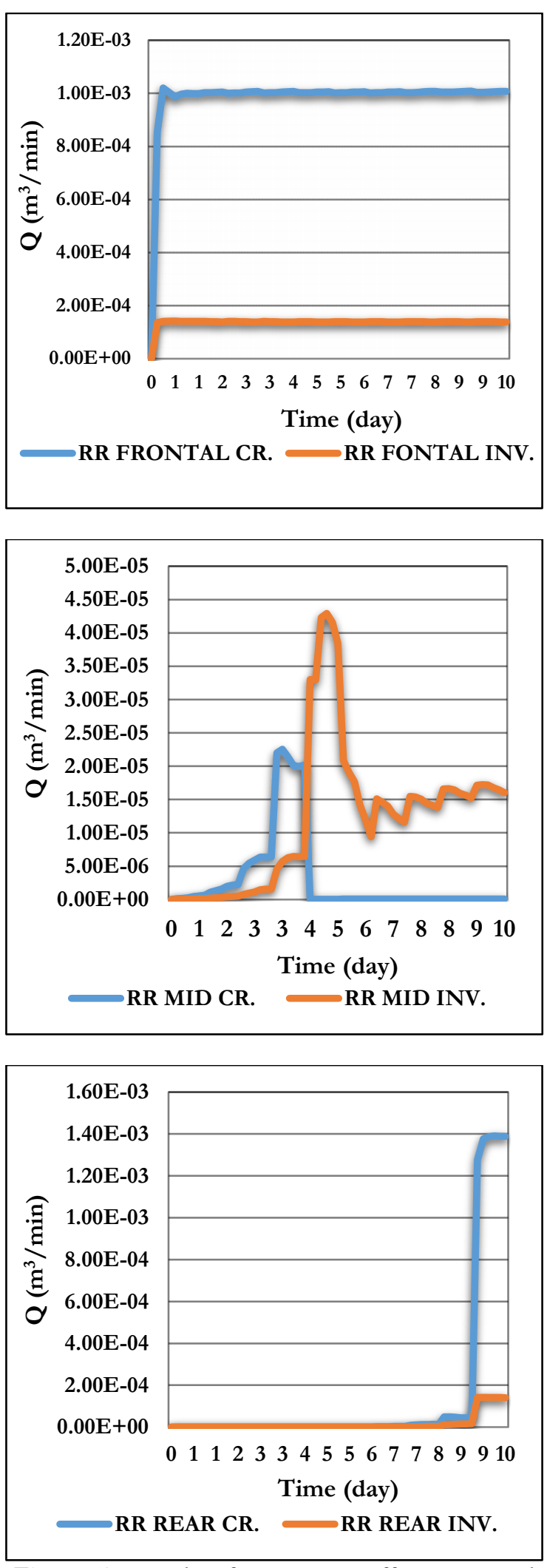

Figure (8): Results of seepage rate effects on tunnel (A) frontal left face (B) mid left plane (C) rear left plane (D) frontal right plane (E) mid right plane, and (F) rear right plane \& for Tigris water level equal 1.8 $\mathrm{m}$.
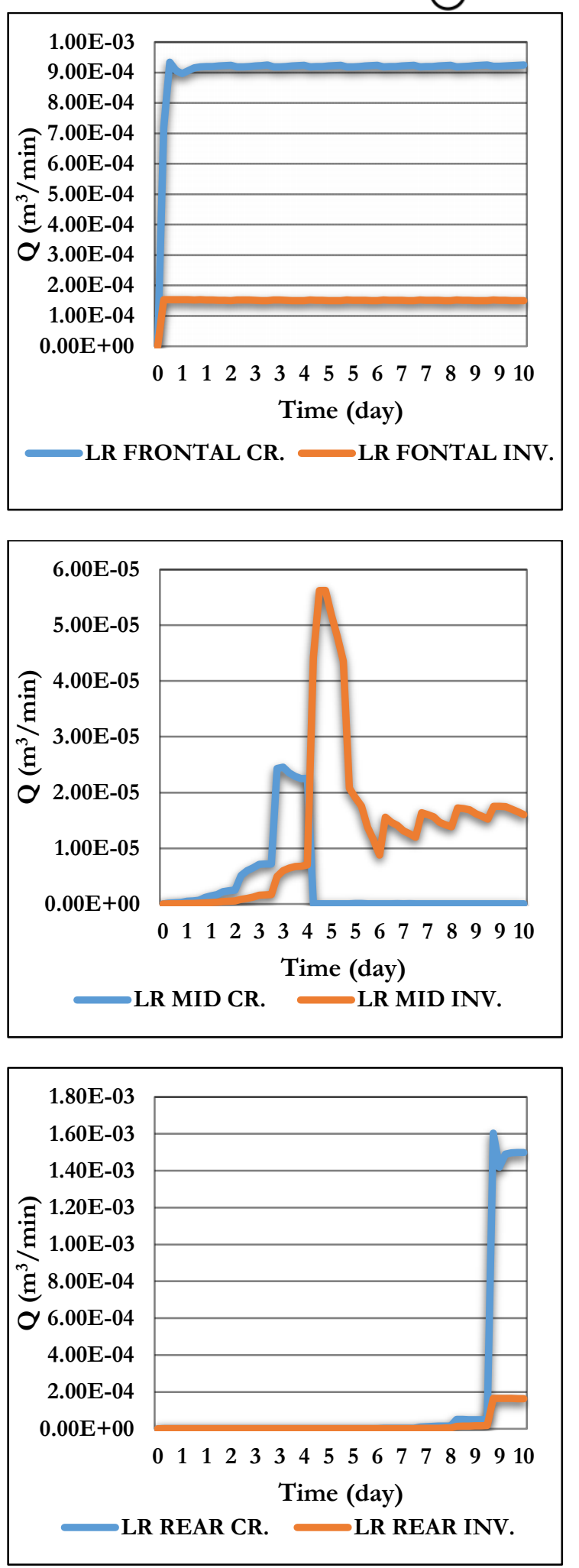

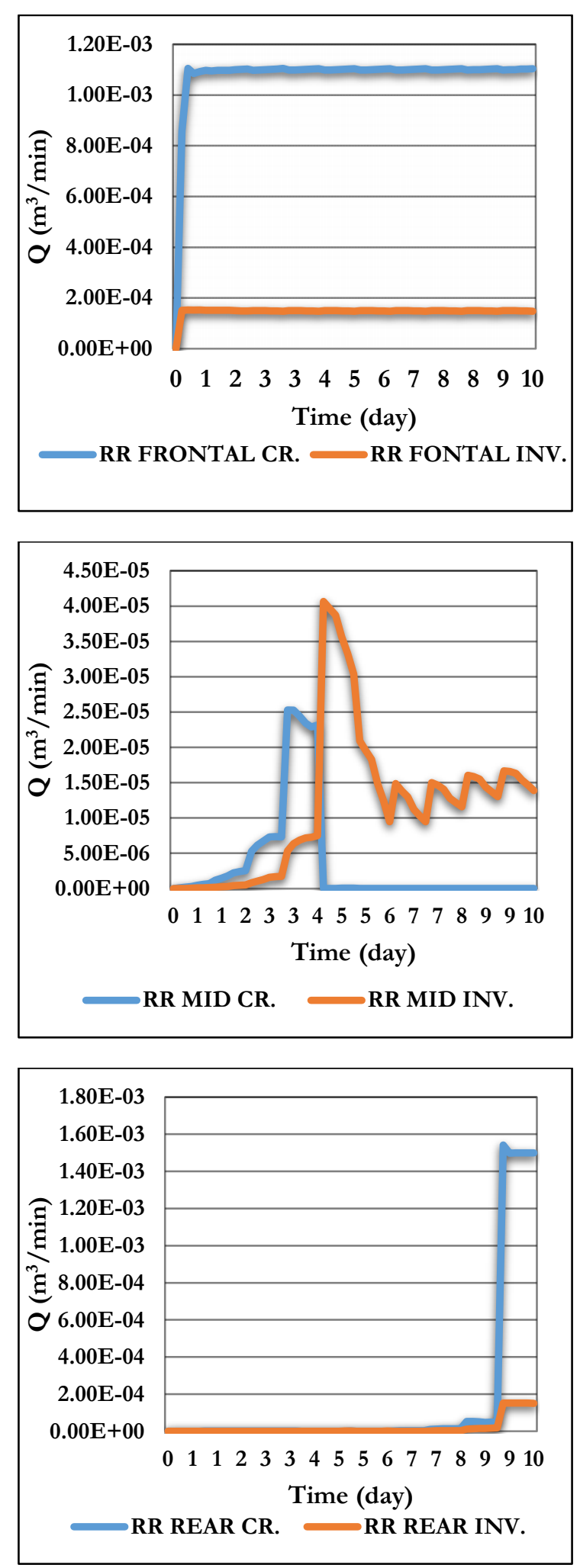

Figure (9): Results of seepage rate effects on tunnel (A) frontal left face (B) mid left plane (C) rear left plane (D) frontal right plane (E) mid right plane, and (F) rear right plane \& for Tigris water level equal 3.9 $\mathrm{m}$.

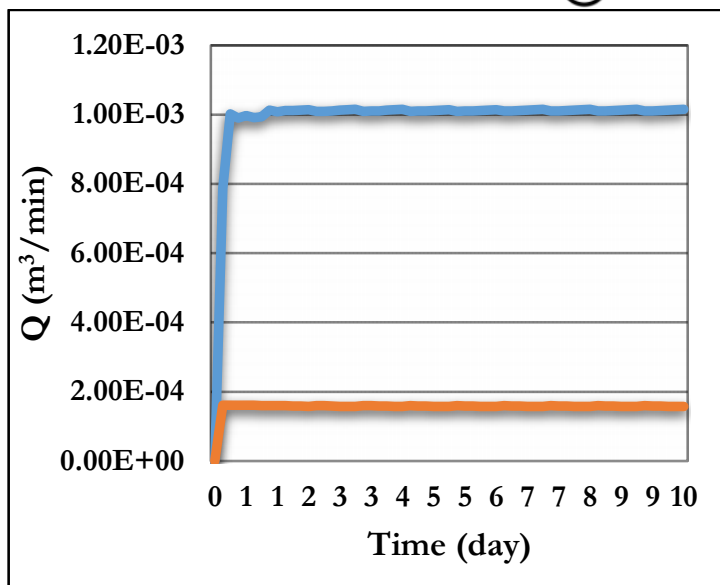

LR FRONTAL CR. LR FONTAL INV.
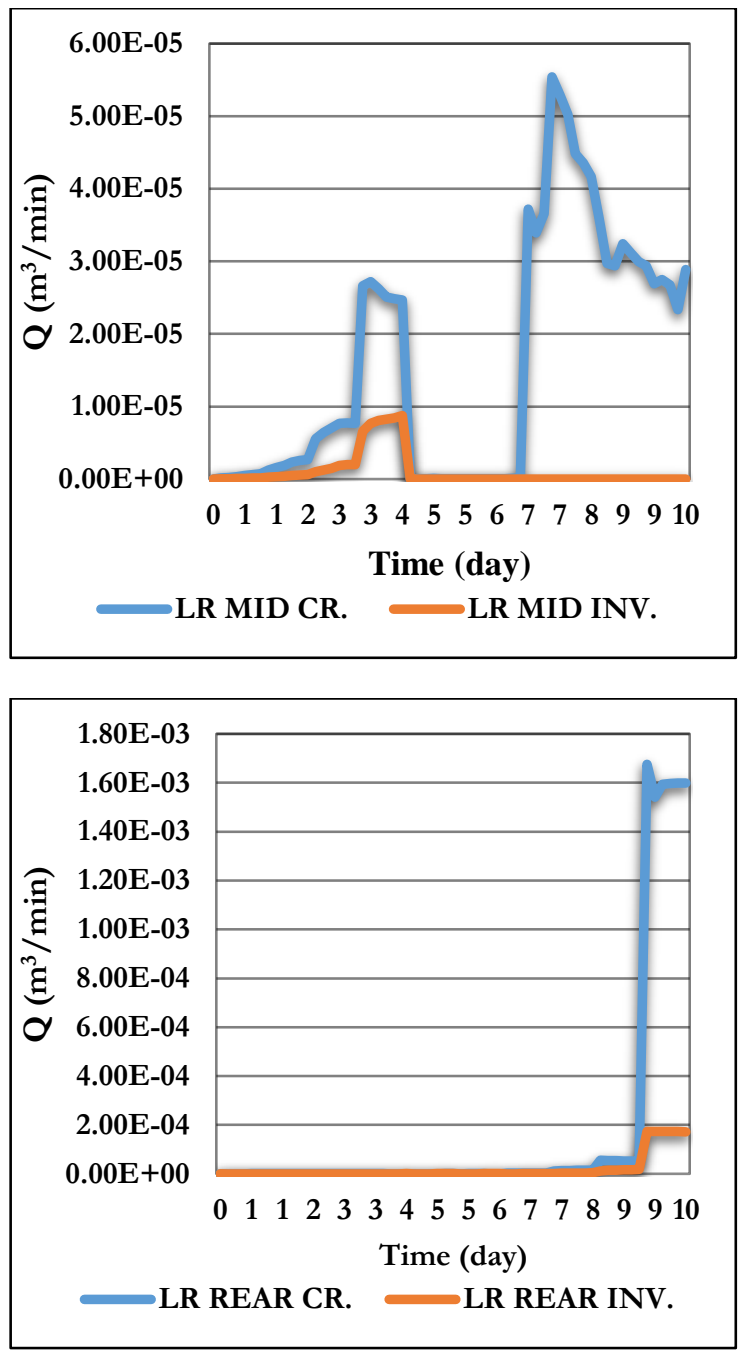

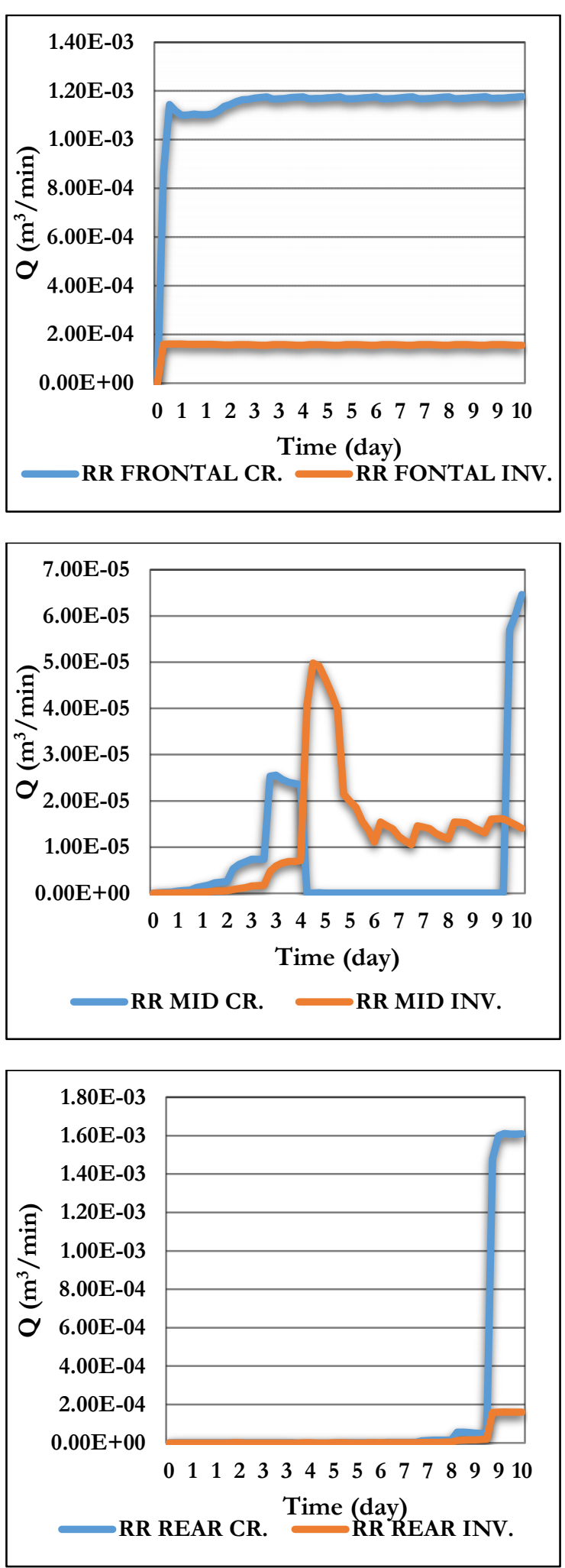

Figure (10): Results of seepage rate effects on tunnel

(A) frontal left face (B) mid left plane (C) rear left

plane (D) frontal right plane (E) mid right plane, and

(F) rear right plane \& for Tigris water level equal 6.0

$\mathrm{m}$

\section{Conclusions}

The results prove that the water level change during different seasons of the year affects the seepage rate, but not the behavior, during the excavation stage of the proposed metro tunnel. The most critical point is the crest point of the rear face of tunnel, were occurred at the end of the excavation stage (day 10). The seepage rate at the invert points of both routes is approximately linear with mostly negligible value $\left(10^{-5} \mathrm{~m}^{3} / \mathrm{min}\right)$, and its value is slightly affected by the change in water level. The increase of water level from (1.8) meters to (6.1) meters caused increasing in the maximum water inflow by roughly $15 \%$ due to the increase in pore water pressure [7]. The frontal and rear faces exhibit higher values for seepage rate at their crest points as compared to the invert point of the same section and for the selected water level. On the other hand, the mid-way section crest points exposed to lower seepage forces as compared to the same section invert point.

\section{References}

[1] Zhang Z., Zhang X., Sun Sh. \& Liang Z. , 2019, A cross-river tunnel excavation considering the water pressure effect based on DEM, European Journal of Environmental and Civil Engineering,

[2] Zhang, W., Dai, B., Liu, Z., Zhou, C., 2017. On the non-Darcian seepage flow field around a deeply buried tunnel after excavation. Bull. Eng. Geol. Environ. of the International Association of Engineering Geologists 2, no. 1: 39-56.

[3]Pujades E., Jesus C., Enric V.S., Anna J., Victor V., Eduardo M.S., 2012, Hydraulic characterization of diaphragm walls for cut and cover tunnelling, Engineering Geology, Volume 125, Pages 1-10

[4] P. Perazzelli , T. Leone, G. Anagnostou, 2014, Tunnel face stability under seepage flow conditions, Tunnelling and Underground Space Technology, Volume 43, pp 459-469.

[5] Font-Capó, J., 2012. "Interaction between Ground Water and TBM (Tunnel Boring Machine) Excavated Tunnels", Ph. D. Thesis, Department of Geotechnical Engineering and Geosciences, Technical University of Catalonia, Catalonia, Spain.

[6] Goodman, R.E., D.G. Moye, A. Van Schalkwyk, and I. Javandel. 1965. Ground water inflows during tunnel driving. Bulletin.

[7] Katibeh H. and Aalianvari A. 2014. "Common Approximations to the Water Inflow into Tunnels", PhD thesis, Amirkabir University of Technology and Hamedan University of Technology.

[8] L.Zhang J.A.Franklin, 1993, Prediction of Water seepage into rock tunnels: an analytical solution assuming an hydraulic conductivity gradient, Volume 30, Issue 1, Pages 37-46

[9] Heuer, R.E., 1995. Estimating rock tunnel water inflow. In: Rapid Excavation and Tunneling Conference, pp. 41-60 (Chapter 3).

[10] El Tani, M. 1999. Water inflow into tunnels. In Proceedings of the World Tunnel Congress ITAAITES, Oslo, Norway, Balkema, 61-70.

[11] Karlsrud, K., 2001. Water control when tunnelling under urban areas in the Olso region. NFF publication No. 12, 4, 27-33, NFF.

[12] Moon, J., and G. Fernandez. 2010. Effect of excavation-induced groundwater level drawdown on tunnel inflow in a jointed rock mass. Engineering Geology 110, no. 3: 33-42.

[13] Young-JinShin, Byoung-MinKim, Jong-HoShin, In-MoLee, 2010, The ground reaction curve of 
underwater tunnels considering seepage force,

Tunnelling and Underground Space Technology

Volume 25, Issue 4, July 2010, Pages 315-324

[14] L. Zhang, D. Zhao, J. Wu, W. Yang, W. Wang, D. $\mathrm{Xi}, 2020$, Prediction of water inflow in Tsingtao subsea tunnel based on the superposition principle, Tunnelling and Underground Space Technology, volume 97

[15] NCCLR: National Center for Construction Labs and Researches, Baghdad, Iraq.

[16] Mayoralty of Baghdad, Baghdad, Iraq.

[17] PLAXIS 3D Manual (2020), Delt University of Technology \& PLAXIS bv, Netherland.

[18] Kai Su, Yafeng Zhou, Hegao Wu, Changzheng Shi, Li Zhou, 2017, An Analytical Method for Groundwater Inflow into a Drained Circular Tunnel, Groundwater Summit, Volume55, Issue5 , Pages 712721.

[19] Zhou, Y.F., K. Su, and H.G. Wu. 2014. Study of external water pressure estimation method for reinforced concrete lining of hydraulic tunnels. Yantu Lixue/Rock and Soil Mechanics 35, no. S2: 198-202, 210.

[20] Isacc S. Alakaam, 2010, A study of some morphological characteristics of the Tigris River in the city of Baghdad, University of Baghdad - College of Science (Arabic language).

[21] Yoo, C. and Kim, S. B., 2008. "ThreeDimensional Numerical Investigation of Multifaced Tunnelling in Water-Bearing Soft Ground", Canadian Geotechnical Journal, 45: 1467-1486, NRC Research Press. 